\title{
Synthesis, characterization, ab initio calculations, thermal behaviour and thermodynamics of some oxovanadium(IV) complexes involving O,O- and $N, N$-donor moieties
}

\author{
MOZAFFAR ASADI $^{\mathrm{a}, *}$, MOHAMMAD HADI GHATEE $^{\mathrm{a}}$, SUSAN TORABI ${ }^{\mathrm{a}}$, \\ KHOSRO MOHAMMADI ${ }^{\mathrm{b}}$ and FATEMEH MOOSAVI ${ }^{\mathrm{a}}$ \\ ${ }^{a}$ Chemistry Department, College of Sciences, Shiraz University, Shiraz 71454, I.R. Iran \\ ${ }^{\mathrm{b}}$ Chemistry Department, Faculty of Sciences, Persian Gulf University, Bushehr 75169, I.R. Iran \\ e-mail: mozaffarasadi@yahoo.com; asadi@susc.ac.ir
}

MS received 4 November 2009; revised 13 March 2010; accepted 30 March 2010

\begin{abstract}
Some oxovanadium(IV) complexes, namely bis(1,1,1-trifluro-2,4-pentanedionato- $\left.O, O^{\prime}\right)$ oxovanadium (IV), [VO $\left.(\mathrm{tfac})_{2}\left(\mathrm{H}_{2} \mathrm{O}\right)\right]$, bis(1-phenyl-2,4-pentanedionato- $\left.O, O^{\prime}\right)$ oxovanadium(IV), [VO (phac) $\left.)_{2}\left(\mathrm{H}_{2} \mathrm{O}\right)\right]$, bis(1,3-diphenyl-2,4-pentanedionato- $\left.O, O^{\prime}\right)$ oxovanadium(IV), [VO $\left.(\text { dphac })_{2}\left(\mathrm{H}_{2} \mathrm{O}\right)\right]$, of the type $\left[\mathrm{VO}\left(\mathrm{O}_{4}\right)\right]$ and bis(pyrolidineaniline)oxovanadium(IV), [VO(pyran $\left.)_{2}\left(\mathrm{H}_{2} \mathrm{O}\right)\right]$, bis(p-hydroxypyrolidineaniline)oxovanadium $(\mathrm{IV}), \quad\left[\mathrm{VO}(p \text {-hydroxypyran })_{2}\left(\mathrm{H}_{2} \mathrm{O}\right)\right], \quad$ bis $(p$-methoxypyrolidineaniline $)$ oxovanadium(IV), [VO $\left.(p \text {-MeOpyran })_{2}\left(\mathrm{H}_{2} \mathrm{O}\right)\right]$, bis(p-chloropyrolidineaniline)oxovanadium(IV), [VO $(p$ chloropyran $\left.)_{2}\left(\mathrm{H}_{2} \mathrm{O}\right)\right]$, bis ( $p$-bromopyrolidineaniline)oxovanadium(IV), [VO(p-bromopyran $\left.)_{2}\left(\mathrm{H}_{2} \mathrm{O}\right)\right]$, bis ( $p$-cyano pyrolidineaniline)oxovanadium(IV), [VO $\left.(p \text {-cyanopyran })_{2}\left(\mathrm{H}_{2} \mathrm{O}\right)\right]$, and bis (pyrolidinebenzylamine)oxovanadium(IV), [VO $\left.(\text { pyrbz })_{2}\left(\mathrm{H}_{2} \mathrm{O}\right)\right]$, of the type $\left[\mathrm{VO}\left(\mathrm{N}_{4}\right)\right]$ were synthesized and characterized by IR, UV-Vis, mass spectrometry, elemental analysis, magnetic moment and thermogravimetry in order to evaluate their thermal stability and thermal decomposition pathways. The number of steps and, in particular, the starting temperature of decomposition of these complexes depends on the equatorial ligand. Also, formation constants of the complexes have been determined by UV-Vis absorption spectroscopy through titration of the ligands with the metal ions at constant ionic strength $\left(0 \cdot 1 \mathrm{M} \mathrm{NaClO}_{4}\right)$ and at $25^{\circ} \mathrm{C}$. According to the thermodynamic studies, as the steric character of the ligand increases, the complexation tendency to $\mathrm{VO}(\mathrm{IV})$ center decreases. Also, the $a b$ initio calculations were carried out to determine the structural and the geometrical properties of the complexes.
\end{abstract}

Keywords. Oxovanadium(IV); formation constants; thermodynamic; ab initio calculations.

\section{Introduction}

In recent years, vanadium chemistry has attracted attention due to its interesting structural features and biological relevance. ${ }^{1-7}$ Vanadium oxide (vanadyl) complexes, in particular, have come under close scrutiny because of their utility as insulin mimetics. ${ }^{2}$ Peroxovanadium complexes ${ }^{8-12}$ and bis-(maltolato) oxovanadium(IV) ${ }^{13,14}$ (VO(malto) ${ }_{2}$ ) have been found to be more effective than the simple vanadium(IV) and $-(\mathrm{V})$ salts, both in cell cultures and in animal studies. Furthermore, a bis(maltolato)oxovanadium (IV) derivative (KP-102) has now entered phase I clinical trials in humans. A related compound, bis(2,4-pentanedionato- $O, O^{\prime}$ )oxovanadium(IV) (VO $\left.(\mathrm{acac})_{2}\right)$ was also found to have insulin-mimetic

*For correspondence properties superior to those of $\mathrm{VOSO}_{4}$ in cell culture studies. ${ }^{15}$

Since the first published account of the synthesis of $\mathrm{VO}(\mathrm{acac})_{2}$ in $1914,{ }^{16}$ the complex has been used extensively as a reagent in organic synthesis. ${ }^{17-19}$ The physical properties of $\mathrm{VO}(\mathrm{acac})_{2}$ have been examined by numerous workers, ${ }^{20-22}$ and the crystal structure was published in $1962 .{ }^{23}$ In the solid state, $\mathrm{VO}(\mathrm{acac})_{2}$-type complexes are five-coordinate; however, upon dissolution in organic solvents, the vanadium coordinates a donor ligand in the vacant site, generating products expressed as [VO $\left.(\mathrm{acac})_{2} \mathrm{~L}\right]$ (where $\mathrm{L}=$ coordinated ligand and acac is 2,4pentanedionato or corresponding acac- derivatives).

In view of importance of vanadium compounds, and also extending the search for more efficacious compounds, this study is undertaken of the synthesis and coordination chemistry of some oxovana- 
dium(IV) complexes of the type $\left[\mathrm{VO}\left(\mathrm{O}_{4}\right)\right]$ and [VO( $\left.\left.\mathrm{N}_{4}\right)\right]$ involving some diketone and some pyrrolecarbaldehyde derivatives.

The resulting complexes have been characterized on the basis of elemental analysis $(\mathrm{C}, \mathrm{H}, \mathrm{N})$, infrared, mass and electronic spectral techniques. Thermal stability is an important feature of the complexes in their potential applications as catalysts, so the differences observed in the thermal behaviour of [ $\left.\mathrm{VO}\left(\mathrm{O}_{4}\right)\right]$-type complexes is described by using thermogravimetry (TG). Also the formation constants of the complexes were determined spectrophotometrically at $25^{\circ} \mathrm{C}$ in methanol.

In addition to the importance of the experimental studies, it is crucial to investigate the theoretical behaviour of target complexes to find their structural characteristics and the way that these structures affect the other properties of the complexes. The structure of a complex can be studied by the $a b$ initio methods to find the stable structure electronically by solving the wave function of the molecule. The theoretical goal of this study focuses on these features of the chemistry.

\section{Experimental}

\subsection{Reagents}

Diketones, aniline and its derivatives were purchased from Aldrich and were used as received. All other solvents and reagents with analytical grade (PA) were obtained commercially and used without further purification.

\subsection{Physical measurements}

All of the scanning UV-Vis spectra were recorded on Perkin-Elmer Lambda 2 spectrophotometer. FTIR spectra were run on a Shimadzu FTIR-8300 spectrophotometer. Mass spectra were obtained with Shimadzu LCMS-2010EV. The Elemental analysis was carried out by Thermo Finnigan-Flash-1200. The NMR spectra were recorded by a Bruker Avance DPX $250 \mathrm{MHz}$ spectrometer.

\subsection{Preparation of the vanadyl complexes}

2.3a $\left[\mathrm{VO}\left(\mathrm{O}_{4}\right)\right]$-type: $\left[\mathrm{VO}(\mathrm{dphac})_{2}\left(\mathrm{H}_{2} \mathrm{O}\right)\right]$, [VO $(\text { phac })_{2}$ $\left.\left(\mathrm{H}_{2} \mathrm{O}\right)\right]$, [VO (tfac $\left.)_{2}\left(\mathrm{H}_{2} \mathrm{O}\right)\right]$, were prepared by the same general procedure. ${ }^{24}$ Vanadyl sulphate tri- hydrate $(0.163 \mathrm{~g}, 1 \mathrm{mmol})$ was dissolved in $10 \mathrm{ml}$ $10 \% \mathrm{H}_{2} \mathrm{SO}_{4}$. Then diketone was dissolved in $10 \mathrm{ml}$ methanol and added. The resulting solution was $\mathrm{pH}$ adjusted with $10 \%$ sodium bicarbonate solution to $\mathrm{pH}$ 4.0. A green precipitate began to form and was collected by filtration. These materials were purified by dissolving the complexes in chloroform, as neither the vanadyl hydroxide nor sodium bicarbonate is soluble in this solvent. The solid compound was obtained by evaporation of the solvent to dryness. Structural representations of the complexes with their abbreviations are given in figure 1.

$2.3 \mathrm{~b}\left[\mathrm{VO}\left(\mathrm{N}_{4}\right)\right]$-type: $1 \mathrm{mmol}$ of pyrrol-2-carbaldehyde was mixed with $10 \mathrm{ml}$ of ethanol and then added to the ethanolic solution of $1 \mathrm{mmol}$ aniline derivatives $(1 \mathrm{M})$, magnetically stirred with the addition of 2 to 3 drops of concentrated triethylamine, refluxed for $2 \mathrm{~h}$ and left overnight at room temperature. The solid product formed was filtered, washed with ethanol and ether consecutively. It was dried at room temperature and recrystallized with hot ethanol to give the required Schiff base. Table 1 shows the analytical data of the prepared compounds.

2.3c Synthesis of the Schiff base complexes: To a $2 \mathrm{mmol} p$-pyrolidineaniline in $10 \mathrm{ml}$ of ethanol was added $1 \mathrm{mmol}$ of $\mathrm{VOSO}_{4} \cdot 5 \mathrm{H}_{2} \mathrm{O}$ in $10 \mathrm{ml}$ of water, when coloured solid precipitated immediately. After refluxing the mixture for approximately $1 \mathrm{~h}$, the solid mass was filtered by suction and repeatedly washed with $1: 1$ ethanol-water mixture and dried in vacuum.

\subsection{Computational details}

The relative stability and molecular properties of the structures under investigation were determined by

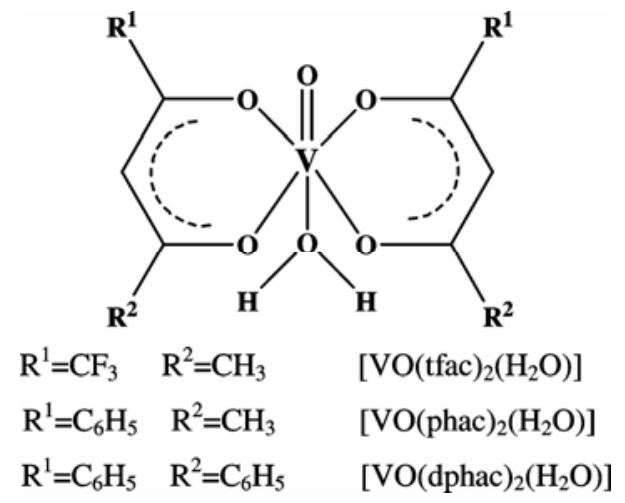

Figure 1. The structural representations of the complexes of $\mathrm{VO}\left(\mathrm{O}_{4}\right)$ type. 


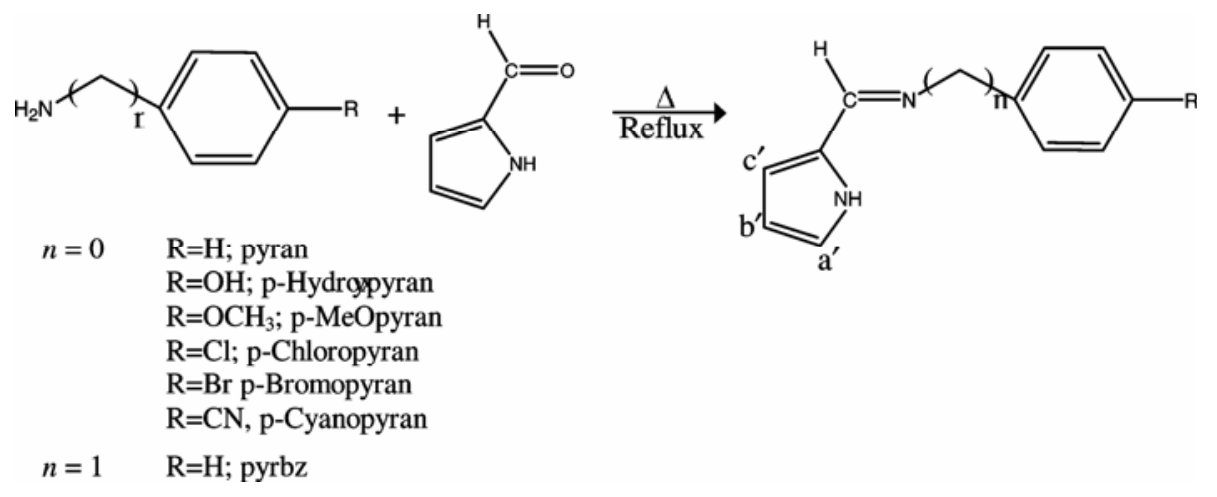

Figure 2. The structural representations of the pyrolidineaniline ligands.

Table 1. Physicoanalytical properties.

\begin{tabular}{lclc}
\hline Compound & m.p. $\left({ }^{\circ} \mathrm{C}\right)$ & \multicolumn{1}{c}{ Colour } & Yield \% \\
\hline$\left[\mathrm{VO}(\mathrm{tfac})_{2}\left(\mathrm{H}_{2} \mathrm{O}\right)\right]$ & 230 & Green & 55 \\
{$\left[\mathrm{VO}(\text { phac })_{2}\left(\mathrm{H}_{2} \mathrm{O}\right)\right]$} & 220 & Green & 52 \\
{$\left[\mathrm{VO}(\text { dphac })_{2}\left(\mathrm{H}_{2} \mathrm{O}\right)\right]$} & 250 & Green & 58 \\
Pyran & 98 & Pale brown & 61 \\
$p$-Hydroxypyran & 192 & Brownish-yellow & 61 \\
$p$-MeOpyran & 98 & Pale-brown & 65 \\
$p$-Chloropyran & 95 & Pale-brown & 71 \\
$p$-Bromopyran & 82 & Brown & 60 \\
$p$-Cyanopyran & 110 & Pale-brown & 67 \\
Pyrbz & 105 & Brown & 63 \\
{$\left[\mathrm{VO}(\text { pyran })_{2}\left(\mathrm{H}_{2} \mathrm{O}\right)\right]$} & $>250$ & Olive-green & 58 \\
{$\left[\mathrm{VO}(p \text {-Hydroxypyran })_{2}\left(\mathrm{H}_{2} \mathrm{O}\right)\right]$} & $>250$ & Green & 50 \\
{$\left[\mathrm{VO}(p \text {-MeOpyran })_{2}\left(\mathrm{H}_{2} \mathrm{O}\right)\right]$} & $>250$ & Green & 55 \\
{$\left[\mathrm{VO}(p \text {-Chloropyran })_{2}\left(\mathrm{H}_{2} \mathrm{O}\right)\right]$} & $>250$ & Green & 58 \\
{$\left[\mathrm{VO}(p \text {-Bromopyran })_{2}\left(\mathrm{H}_{2} \mathrm{O}\right)\right]$} & $>250$ & Brownish-green & 52 \\
{$\left[\mathrm{VO}(p \text {-Cyanopyran })_{2}\left(\mathrm{H}_{2} \mathrm{O}\right)\right]$} & $>250$ & Green & 48 \\
{$\left[\mathrm{VO}(\text { pyrbz })_{2}\left(\mathrm{H}_{2} \mathrm{O}\right)\right]$} & $>250$ & Brownish-green & 60 \\
\hline
\end{tabular}

molecular mechanics and Hartree-Fock (HF) quantum methods. The standard $6-311 \mathrm{~g}$ basis set was used in conjunction with the HF method. All the calculations were performed by using GAUSSIAN03 program package. ${ }^{25}$

Optimized geometries and relative stabilities of three conformers of gaseous $\left[\mathrm{VO}(\mathrm{phac})_{2}\left(\mathrm{H}_{2} \mathrm{O}\right)\right]$ and two conformers of $\left[\mathrm{VO}(\text { pyran })_{2}\left(\mathrm{H}_{2} \mathrm{O}\right)\right]$ have been determined at $\mathrm{MM} / / \mathrm{HF} / 6-31 \mathrm{lg}$ level of theory. The atomic charges in addition to the structural analyses have been employed to interpret the difference among the conformers of the electronic structure and the origin of their relative stabilities. The results of the structural calculations have been used in order to compute the quantitative structure activity relationships $(\mathrm{QSAR})^{26,27}$ properties involving Van der Waals and solvent-accessible surface areas, ${ }^{28}$ hydration energy, ${ }^{29}$ solvent-accessible surfacebounded molecular volume, $\log P$ (the $\log$ of the complex-water partition coefficient) ${ }^{30}$ a measure of hydrophobicity, molar refractivity ${ }^{30,31}$ and polarizability.

Quantitative structure activity relationships (QSAR) are attempts to correlate molecular structure, or properties derived from molecular structure, with a particular kind of chemical or biochemical activity. The kind of activity is a function of the interest of the user: QSAR is widely used in pharmaceutical, environmental, and agricultural chemistry in the search for particular properties. The molecular properties used in the correlations relate as directly as possible to the key physical or chemical processes taking place in the target activity. 
Table 2. UV-Vis ${ }^{\mathrm{a}}$, mass spectral, elemental analysis and magnetic moments data of the compounds.

\begin{tabular}{|c|c|c|c|c|c|c|}
\hline \multirow[b]{2}{*}{ Compounds } & \multirow[b]{2}{*}{$\lambda_{\max }(\mathrm{nm})$} & \multirow[b]{2}{*}{$\begin{array}{c}\text { Mass spectra } \\
(m / z)\end{array}$} & \multicolumn{3}{|c|}{ Elemental analysis (\%, Found) } & \multirow[b]{2}{*}{$\begin{array}{c}M_{\text {eff }} \text { B.M. } \\
(298 \mathrm{~K})\end{array}$} \\
\hline & & & $\mathrm{C}$ & $\mathrm{H}$ & $\mathrm{N}$ & \\
\hline$\left[\mathrm{VO}(\mathrm{tfac})_{2}\left(\mathrm{H}_{2} \mathrm{O}\right)\right]^{\mathrm{a}}$ & 296 & $373,218,150$ & $30 \cdot 71(30 \cdot 60)$ & $2 \cdot 58(2 \cdot 21)$ & & $1 \cdot 65$ \\
\hline$\left[\mathrm{VO}(\mathrm{phac})_{2}\left(\overline{\mathrm{H}}_{2} \mathrm{O}\right)\right]^{\mathrm{a}}$ & 326 & $389,228,161$ & $58.98(59 \cdot 36)$ & $4.95(4.57)$ & & $1 \cdot 68$ \\
\hline$\left[\mathrm{VO}(\mathrm{dphac})_{2}\left(\mathrm{H}_{2} \mathrm{O}\right)\right]^{\mathrm{a}}$ & 356 & $513,289,223$ & $67.80(67.88)$ & $4 \cdot 55(4 \cdot 39)$ & & 1.66 \\
\hline pyran ${ }^{b}$ & 320 & 170 & $71 \cdot 91(72 \cdot 10)$ & $6 \cdot 31(6 \cdot 02)$ & $15 \cdot 25(15 \cdot 65)$ & \\
\hline$p$-Hydroxypyran ${ }^{\mathrm{b}}$ & $295(s h), 335$ & 187,170 & $70 \cdot 27(70 \cdot 39)$ & $5 \cdot 47(5 \cdot 50)$ & $14.90(14.70)$ & \\
\hline$p$-MeOpyran & $297(s h), 332$ & 200,170 & $71.98(71.82)$ & $6.04(6 \cdot 04)$ & $13.99(13.97)$ & \\
\hline$p$-Chloropyran ${ }^{\mathrm{b}}$ & 326 & 204,170 & $62 \cdot 36(62 \cdot 10)$ & $4 \cdot 66(4 \cdot 32)$ & $13 \cdot 22(12 \cdot 88)$ & \\
\hline$p$-Bromopyran & 271,343 & 249,170 & $73 \cdot 15(72 \cdot 81)$ & $4 \cdot 71(5 \cdot 01)$ & $21.33(21 \cdot 10)$ & \\
\hline$p$-Cyanopyran ${ }^{\mathrm{b}}$ & 326 & 195,170 & $70 \cdot 57(70 \cdot 68)$ & $4.94(5.08)$ & $20 \cdot 57(21 \cdot 11)$ & \\
\hline pyrbz & 280 & 184 & $74.58(74.65)$ & $6.78(7 \cdot 01)$ & $14 \cdot 50(14 \cdot 10)$ & \\
\hline$\left[\mathrm{VO}(\text { pyran })_{2}\left(\mathrm{H}_{2} \mathrm{O}\right)\right] \cdot 0.25 \mathrm{H}_{2} \mathrm{O}^{\mathrm{b}}$ & 237,364 & $405,236,169$ & $61.76(61.44)$ & $4.83(4.52)$ & $13 \cdot 09(13 \cdot 33)$ & $1 \cdot 65$ \\
\hline$\left[\mathrm{VO}(\mathrm{p}-\mathrm{Hydroxypyran})_{2}\left(\mathrm{H}_{2} \mathrm{O}\right)\right]^{\mathrm{b}}$ & 300,380 & $437,252,186$ & $58 \cdot 03(58 \cdot 10)$ & $4.43(4.60)$ & $12 \cdot 30(12 \cdot 26)$ & 1.67 \\
\hline$\left[\mathrm{VO}(\mathrm{p}-\mathrm{MeOpyran})_{2}\left(\mathrm{H}_{2} \mathrm{O}\right)\right]^{\mathrm{b}}$ & 381 & $465,265,200$ & $59.63(59.95)$ & $5.00(5.04)$ & $11 \cdot 59(11 \cdot 31)$ & 1.63 \\
\hline$\left[\mathrm{VO}(\mathrm{p}-\mathrm{Chloropyran})_{2}\left(\mathrm{H}_{2} \mathrm{O}\right)\right]^{\mathrm{b}}$ & 243,370 & $473,268,204$ & $53.68(53.85)$ & $3.69(4 \cdot 10)$ & $11 \cdot 38(11.46)$ & $1 \cdot 70$ \\
\hline$\left[\mathrm{VO}(\mathrm{p}-\mathrm{Bromopyran})_{2}\left(\mathrm{H}_{2} \mathrm{O}\right)\right]^{\mathrm{b}}$ & 211,271 & $560,314,247$ & $45 \cdot 47(45 \cdot 12)$ & $3 \cdot 12(3 \cdot 12)$ & $9 \cdot 64(9 \cdot 46)$ & 1.69 \\
\hline$\left[\mathrm{VO}(\mathrm{p}-\mathrm{Cyanopyran})_{2}\left(\mathrm{H}_{2} \mathrm{O}\right)\right]^{\mathrm{b}}$ & 242,371 & $455,261,194$ & $60 \cdot 89(60 \cdot 82)$ & $3.83(3.98)$ & $17.75(17 \cdot 88)$ & 1.66 \\
\hline$\left[\mathrm{VO}(\mathrm{pyrbz})_{2}\left(\mathrm{H}_{2} \mathrm{O}\right)\right] 0 \cdot 5 \mathrm{H}_{2} \mathrm{O}^{\mathrm{b}}$ & 240,326 & $433,250,183$ & $62 \cdot 61(62 \cdot 22)$ & $5.47(5 \cdot 80)$ & $12 \cdot 17(12 \cdot 48)$ & $1 \cdot 64$ \\
\hline
\end{tabular}

${ }^{\text {a }}$ Solvent is $\mathrm{CH}_{3} \mathrm{OH}$. ${ }^{\mathrm{b}}$ Solvent is $\mathrm{CH}_{3} \mathrm{CN}$

\section{Results and discussion}

\subsection{Characterization of the compounds}

The compounds were synthesized and characterized by ${ }^{1} \mathrm{HNMR}$, IR, magnetic moment, mass, UV-Vis spectroscopy and elemental analysis.

3.1a Magnetic moments and electronic spectra: The effective magnetic moment was measured using a Gouy balance. Data were corrected for diamagnetic contributions using the Pascal's constants. ${ }^{32}$ Oxovanadium $(1 \mathrm{~V})$ complexes show magnetic moment values in the range of 1.64-1.70 BM, which are in accordance with the values reported for oxovanadium(IV) complexes with one unpaired electron $^{33}$ (table 2) indicating that the complexes are monomeric. This is in agreement with the $v(\mathrm{~V}=\mathrm{O})$ obtained.

The ligands show two absorption bands at UV-Visible region. A $n-\pi^{*}$ transition band at $326-$ $410 \mathrm{~nm}$ and a $\pi-\pi^{*}$ transition band at $240-297 \mathrm{~nm}$ are shown in the ligands. These absorption bands show a slight shift to higher energy in the complexes that is evident for unalteration structure of ligands in complexation (table 2).

All the vanadyl(IV) complexes have a band at $340-470 \mathrm{~nm}$ in solvent corresponding to a $d-d$ transition band. This band is not always observed, being often buried beneath a high intensity charge transfer band (or more accurately the low energy tail of that band), and when it is observed it is generally a shoulder (table 2). UV-Vis spectra of pyrbz and its oxovanadium(IV) are shown in figure S1.

3.1b Mass spectra: The mass spectra of the ligands show intense molecular ion peaks $\mathrm{m} / \mathrm{z}$ $M^{+} /(M+H)^{+}$(table 2). The mass spectra of the vanadium(IV) chelates show intense peaks including $\left[\mathrm{VOL}_{2}\right]$ and $\left[\mathrm{VOL}_{2}+\mathrm{H}\right]^{+}$that confirmed a structure of stoichiometry of $2: 1$ for ligands to vanadium(IV). The spectra of the vanadyl(IV) complexes, also show some peaks corresponding to $[\mathrm{VOL}]^{+}$and $\mathrm{L}^{+}$ fragments (table 2).

3.1c Infrared spectra: The solid state properties of the ligands and the vanadyl complexes were examined by infrared spectroscopy. For each of these compounds, the characteristic $v(\mathrm{~V}=\mathrm{O})$ stretching at $920-995 \mathrm{~cm}^{-1}$ was observed, as reported for other oxovanadium(IV) derivatives ${ }^{34}$ and is not present in the spectrum of the free ligands (table S1).

IR spectra of the ligand (table S1) showed the absence of bands at $\sim 1735$ and $3315 \mathrm{~cm}^{-1}$ due to the carbonyl $v(\mathrm{C}=\mathrm{O})$ and $v\left(\mathrm{NH}_{2}\right)$ stretching vibrations and a strong new band appeared at $1612-1633 \mathrm{~cm}^{-1}$ assigned to azomethine $v(\mathrm{HC}=\mathrm{N})$ linkage, showing that amino and aldehyde moieties of the starting 
Table 3. ${ }^{1} \mathrm{HNMR}$ spectroscopic data of the compounds ( $\delta$ in ppm).

\begin{tabular}{|c|c|c|c|c|c|c|}
\hline Compounds & Pyrrol-H & $\mathrm{H}-\mathrm{C}=\mathrm{N}$ & $\mathrm{Ar}-\mathrm{H}$ & $-\mathrm{CH}_{2}-$ & $\mathrm{OH}$ & $\mathrm{CH}_{3}$ \\
\hline Pyran $^{a}$ & $\begin{array}{l}6 \cdot 3^{b^{\prime}} \\
6 \cdot 6^{a^{\prime}} \\
6 \cdot 8^{c^{c^{\prime}}}\end{array}$ & 8.59 & $6 \cdot 93-7 \cdot 93$ & & & \\
\hline$p$-Hydroxypyran ${ }^{\mathrm{b}}$ & $\begin{array}{l}6 \cdot 1^{\mathrm{b}^{\mathrm{b}^{\prime}}} \\
6 \cdot 5^{\mathrm{a}^{^{\prime}}} \\
6 \cdot 7^{\mathrm{c}^{\prime}}\end{array}$ & $8 \cdot 26$ & $6 \cdot 69-7 \cdot 05$ & & $11 \cdot 7$ & \\
\hline$p$-MeOpyran ${ }^{\mathrm{a}}$ & $\begin{array}{l}6 \cdot 3^{\mathrm{b}^{\prime}} \\
6 \cdot 7^{\mathrm{z}^{\mathrm{a}}} \\
6 \cdot 9^{\mathrm{c}^{\prime}}\end{array}$ & $8 \cdot 3$ & $6 \cdot 9-7 \cdot 5$ & & & $3 \cdot 8$ \\
\hline$p$-Chloropyran ${ }^{\mathrm{a}}$ & $\begin{array}{l}6 \cdot 3^{\mathrm{b}^{\prime^{\prime}}} \\
6 \cdot 7^{\mathrm{a}^{\mathrm{c}^{\prime}}} \\
6 \cdot 9^{\mathrm{c}^{\prime}}\end{array}$ & $8 \cdot 2$ & $6 \cdot 9-7 \cdot 3$ & & & \\
\hline$p$-Bromopyran ${ }^{\mathrm{a}}$ & $\begin{array}{l}6 \cdot 4^{\mathrm{b}^{\mathrm{b}^{\prime}}} \\
6 \cdot 8^{\mathrm{a}^{\prime}} \\
7 \cdot 1^{\mathrm{c}^{\mathrm{c}^{\prime}}}\end{array}$ & $8 \cdot 2$ & $7 \cdot 2-7 \cdot 6$ & & & \\
\hline$p$-Cyanopyran ${ }^{\mathrm{b}}$ & $\begin{array}{l}6 \cdot 1^{\mathrm{b}^{\mathrm{b}^{\prime}}} \\
6 \cdot 2^{\mathrm{a}^{\prime}} \\
6 \cdot 7^{\mathrm{c}^{\prime}}\end{array}$ & $9 \cdot 4$ & $6 \cdot 5-7 \cdot 3$ & & & \\
\hline pyrbz $^{\mathrm{a}}$ & $\begin{array}{l}6 \cdot 1^{b^{b^{\prime}}} \\
6 \cdot 4^{a^{\prime}} \\
6 \cdot 7^{7^{c^{\prime}}}\end{array}$ & $8 \cdot 1$ & $7 \cdot 0-7 \cdot 2$ & $4 \cdot 64$ & & \\
\hline
\end{tabular}

${ }^{\mathrm{a}}$ Solvent is $\mathrm{CDCl}_{3} \cdot{ }^{\mathrm{b}}$ Solvent is DMSO- $d_{6}$

material are absent and have been converted into the ligand, i.e. $p$-pyrrolidineaniline.

The comparison of IR spectra of the ligand and its vanadyl complexes indicated that the ligand is principally coordinated to the metal ion in 2 ways, thus acting as a bidentate ligand. The band appearing at $\sim 1630 \mathrm{~cm}^{-1}$ due to azomethine was shifted to a lower frequency by $\sim 1-15 \mathrm{~cm}^{-1}$ in both complexes, indicating participation of azomethine nitrogen in the interaction with the metal ion. The band appearing at $3153-3300 \mathrm{~cm}^{-1}$ assigned to the $v(\mathrm{NH})$ in the ligand was no longer found in the spectra of the metal complexes indicating deprotonation and coordination of the nitrogen with the metal ion.

3.1d ${ }^{1} H N M R$ spectra: ${ }^{1} \mathrm{H}$ NMR spectral data of pyrrolidineaniline ligands show a singlet $(1 \mathrm{H})$ signal at $\delta=10 \cdot 5-12 \mathrm{ppm}$ which can be assigned to the $\mathrm{N}-$ $\mathrm{H}$ of the pyrrol rings. The pyrrol ring proton signals resolved into three groups in the range $\delta=6 \cdot 2$ $7.4 \mathrm{ppm}$ as a triplet and doublet that are related to the protons in position $b$ and $(a, c)$. The signals of the hydrogen of the phenyl group are appeared at $\delta=6.6-8 \mathrm{ppm}$. A singlet signal at $\delta=3.8 \mathrm{ppm}$ is assigned to those compounds that have OMe group. The ${ }^{1}$ HNMR spectra of the ligands provide compel- ling evidence of the presence of one azomethine proton group at $\sim 8.0 \mathrm{ppm}$.

\subsection{Geometry and energy}

The theoretical calculation mainly focuses on the geometries and the relative stability of the possible conformers of $\left[\mathrm{VO}(\text { pyran })_{2}\left(\mathrm{H}_{2} \mathrm{O}\right)\right]$ and $\left[\mathrm{VO}(\mathrm{phac})_{2}\right.$ $\left.\left(\mathrm{H}_{2} \mathrm{O}\right)\right]$. The results of the methods conventionally assumed to explain the relative stability of the complexes. All calculations have been consistent in predicting that the conformer cis is more stable than the trans one in $\left[\mathrm{VO}(\text { pyran })_{2}\left(\mathrm{H}_{2} \mathrm{O}\right)\right]$ complex while the most stable form among all the supposed structures for $\left[\mathrm{VO}(\mathrm{phac})_{2}\left(\mathrm{H}_{2} \mathrm{O}\right)\right]$ is the trans conformer. We have proposed two conformers for the trans, the first one is a conformer with the phenyl groups in the trans position and the other one is that the oxygen atoms connected to the vanadium are in the trans position.

The results of the computation reported in table S2 demonstrates the HF energy for each complex in atomic units. The energy difference is $13.6261 \mathrm{eV}$ for the conformers of the $\left[\mathrm{VO}(\text { pyran })_{2}\left(\mathrm{H}_{2} \mathrm{O}\right)\right]$ complex. This energy difference value in the conformers 


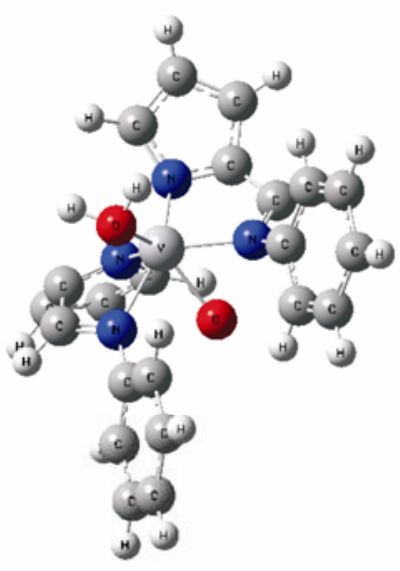

(a)
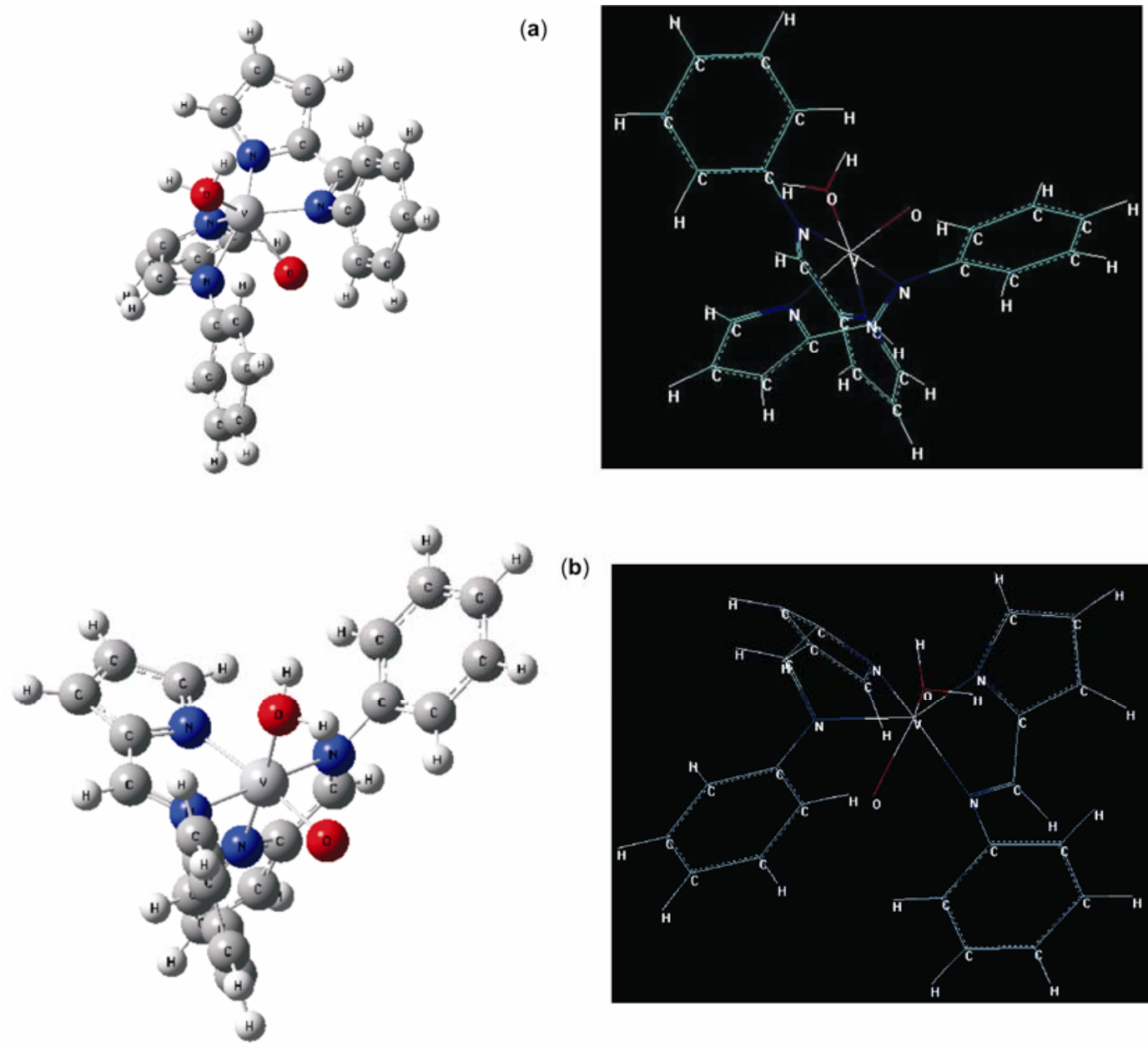

(b)

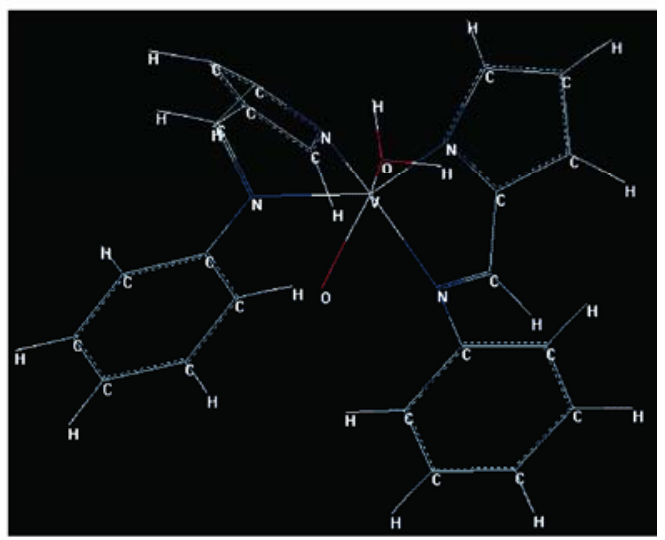

Figure 3. The structure of the (a) cis-[VO(pyran $\left.)_{2}\left(\mathrm{H}_{2} \mathrm{O}\right)\right]$ complex and (b) trans$\left[\mathrm{VO}(\text { pyran })_{2}\left(\mathrm{H}_{2} \mathrm{O}\right)\right]$ complex.

of the $\left[\mathrm{VO}(\mathrm{phac})_{2}\left(\mathrm{H}_{2} \mathrm{O}\right)\right]$ is 0.2685 and $5.6061 \mathrm{eV}$, respectively, for the cis and the trans conformers relative to the most stable conformer. The value of the energies suggests that the lowest-energy form of the $\left[\mathrm{VO}(\mathrm{phac})_{2}\left(\mathrm{H}_{2} \mathrm{O}\right)\right]$ complex in the gas is the trans conformer with a planar structure and having oxygen atoms in the two sides of the molecule plane. However, the trend of stability and the structures of the conformers depend upon the level of the theory. Figure 3 shows the structures of the [VO(pyran $\left.)_{2}\left(\mathrm{H}_{2} \mathrm{O}\right)\right]$. The structures of the conformers of the $\left[\mathrm{VO}(\mathrm{phac})_{2}\left(\mathrm{H}_{2} \mathrm{O}\right)\right]$ complex are presented in the appendix 1 .

\subsection{Thermal analysis}

The thermal decomposition of the $\left[\mathrm{VO}\left(\mathrm{O}_{4}\right)\right]$-type complexes studied in this work presented characteristic pathways, depending on the nature of the ligands, as can be seen from the TG/DTG curves in figure $\mathrm{S} 2$.

The hydrated water molecules are associated with the complex formation and found outside the coordination sphere formed around the central metal ion. The dehydration of this type of water takes place in the temperature range of $25-220^{\circ} \mathrm{C}$. On the other hand, the coordinated water molecules are eliminated at higher temperatures than the water molecules of hydration. The water of coordination is usually eliminated ${ }^{35}$ in the temperature range of $100-316^{\circ} \mathrm{C}$. The organic part of the complexes may decompose in one or more steps with the possibility of the formation of one or two intermediates. These intermediates may include the metal ion with a part of the Schiff base in case of $1: 1$ or $1: 2$ complexes. These intermediates may finally decompose to stable metal oxides.

The thermogravimetric curve of [ $\left.\mathrm{VO}(\mathrm{tfac})_{2}\left(\mathrm{H}_{2} \mathrm{O}\right)\right]$ shows a weight loss of $81.1 \%$ in the temperature 
range of $150-230^{\circ} \mathrm{C}$ with a residue of $19.8 \%$ (calcd. weight loss for $1 \mathrm{~mol}$ of $\mathrm{H}_{2} \mathrm{O}$ and $2 \mathrm{~mol}$ of tfac: $82.1 \%$ ) corresponding to the elimination of one molecule of the coordinated water and 2 tfac groups. According to the DTG curve, the decomposition involves one step (figure $\mathrm{S} 2$, curve a).

The thermal decomposition of $\left[\mathrm{VO}(\mathrm{phac})_{2}\left(\mathrm{H}_{2} \mathrm{O}\right)\right]$ occurs in two steps. The first mass loss (observed $36.6 \%$ ), can be seen between 190 and $307^{\circ} \mathrm{C}$ (calcd. weight loss for $1 \mathrm{~mol}$ of $\mathrm{H}_{2} \mathrm{O}$ and $1 \mathrm{~mol}$ of phac: $42.1 \%$ ) corresponding to the elimination of one molecule of coordinated water and 1 phac group. The decomposition continues with the gradual weight loss, and it ceases at about $480^{\circ} \mathrm{C}$. This weight loss in the temperature range of $370-480^{\circ} \mathrm{C}$ (observed 32.6\%) (calcd. 38.1\%), assuming weight removal of the other coordinated phac group. The final residue with attaining a constant weight (observed 37\%) roughly corresponds to $\mathrm{V}_{2} \mathrm{O}_{5}$ (calcd. $42 \%$ ) (figure $\mathrm{S} 2$, curve $\mathrm{b}$ ).

The $\left[\mathrm{VO}(\mathrm{dphac})_{2}\left(\mathrm{H}_{2} \mathrm{O}\right)\right]$ decomposes in two steps. The first step occurs between 188 and $310^{\circ} \mathrm{C}$ is probably a partial decomposition of the ligand and elimination of one molecule of the coordinated water (observed 42.6\%) (calcd. weight loss for $1 \mathrm{~mol}$ of $\mathrm{H}_{2} \mathrm{O}$ and $1 \mathrm{~mol}$ of phac: $45.0 \%$ ). The second step of the thermal decomposition, which occurs in the range of $360-458^{\circ} \mathrm{C}$, was assigned to the loss of the second ligand (observed 35.3\%) (calcd. $40.7 \%$ ) with the formation of $\mathrm{V}_{2} \mathrm{O}_{5}$ (observed $30 \%$ ) (calcd. 35.0\%) (figure $\mathrm{S} 2$, curve c).

The thermal studies performed suggest that [VO $\left.(\mathrm{tfac})_{2}\left(\mathrm{H}_{2} \mathrm{O}\right)\right]$ is less stable than the other complexes because of the lower degradation temperature (approximately $150^{\circ} \mathrm{C}$ ). The presence of the phenyl group in the coordination sphere of the two other complexes may enhance their stability.

\subsection{Thermodynamic studies of complex formation}

The formation constants, $K_{f}$, of the complexation were determined by spectrophotometric titration of a fixed concentration of the ligands $\left(5 \times 10^{-5} \mathrm{M}\right)$ with various concentrations of the metal sulphate $\left(2.5 \times 10^{-6}-9.75 \times 10^{-5} \mathrm{M}\right)$ at $25^{\circ} \mathrm{C}$ and at constant ionic strength $\left.(0 \cdot 1 \mathrm{M} \mathrm{NaClO})_{4}\right)$. The interaction of $\mathrm{NaClO}_{4}$ with the ligands was negligible. In a typical titration $2.5 \mathrm{~mL}$ of the ligand solution was transferred into the thermostated cell compartment of the UV-Visible instrument, which was kept at constant temperature $\left( \pm 0 \cdot 1^{\circ} \mathrm{C}\right)$ by circulating water, and was titrated by the metal ion solution.

The titration was performed by adding aliquots of the metal ion with a Hamilton $\mu \mathrm{L}$ syringe to the ligand. The absorption measurements were carried out at various wavelengths where the difference in

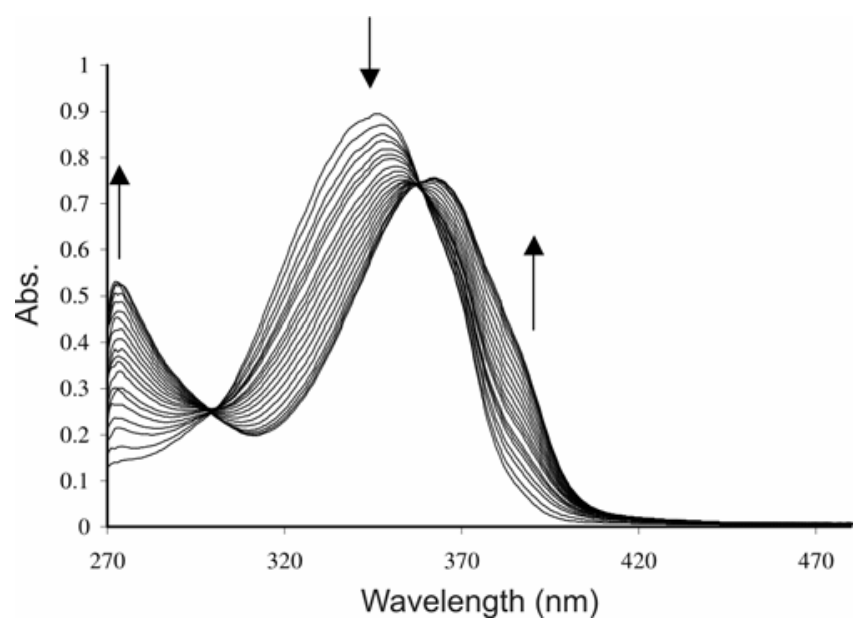

Figure 4. The variation of the electronic spectra of dphac titrared with $\mathrm{VO}\left(\mathrm{SO}_{4}\right) \cdot n \mathrm{H}_{2} \mathrm{O}$ at $25^{\circ} \mathrm{C}$ in $96 \%$ methanol.

Table 4. The formation constants, $\log K_{f}$, for the complexes at $25^{\circ} \mathrm{C}$.

\begin{tabular}{|c|c|c|}
\hline Ligand & $\log K_{f}$ & $\Delta G^{\circ}\left(\mathrm{kJ} \mathrm{mol}^{-1}\right)$ \\
\hline $\operatorname{tfac}^{\mathrm{a}}$ & $8.97 \pm 0.07$ & $-51 \cdot 18 \pm 0 \cdot 11$ \\
\hline phac $^{\mathrm{a}}$ & $8.00 \pm 0.01$ & $-45 \cdot 63 \pm 0.70$ \\
\hline dphac $^{\mathrm{a}}$ & $7.48 \pm 0.06$ & $-42 \cdot 66 \pm 0 \cdot 19$ \\
\hline pyran $^{\mathrm{b}}$ & $10 \cdot 18 \pm 0 \cdot 14$ & $-58.06 \pm 0.07$ \\
\hline$p$-Hydroxypyran ${ }^{\mathrm{b}}$ & $10 \cdot 94 \pm 0.22$ & $-62 \cdot 39 \pm 0.09$ \\
\hline$p$-MeOpyran & $9 \cdot 00 \pm 0 \cdot 06$ & $-51 \cdot 33 \pm 0 \cdot 32$ \\
\hline$p$-Chloropyran ${ }^{\mathrm{b}}$ & $8.48 \pm 0.06$ & $-48 \cdot 36 \pm 0 \cdot 19$ \\
\hline$p$-Bromopyran ${ }^{\mathrm{b}}$ & $8 \cdot 22 \pm 0.43$ & $-46 \cdot 88 \pm 0 \cdot 37$ \\
\hline$p$-Cyanopyran ${ }^{\mathrm{b}}$ & $8.00 \pm 0.05$ & $-42 \cdot 63 \pm 0.44$ \\
\hline pyrbz & $8 \cdot 41 \pm 0.08$ & $-47.96 \pm 0 \cdot 19$ \\
\hline
\end{tabular}

${ }^{\text {a }}$ Solvent is $\mathrm{CH}_{3} \mathrm{OH}$. ${ }^{\mathrm{b}}$ Solvent is $\mathrm{CH}_{3} \mathrm{CN}$ 

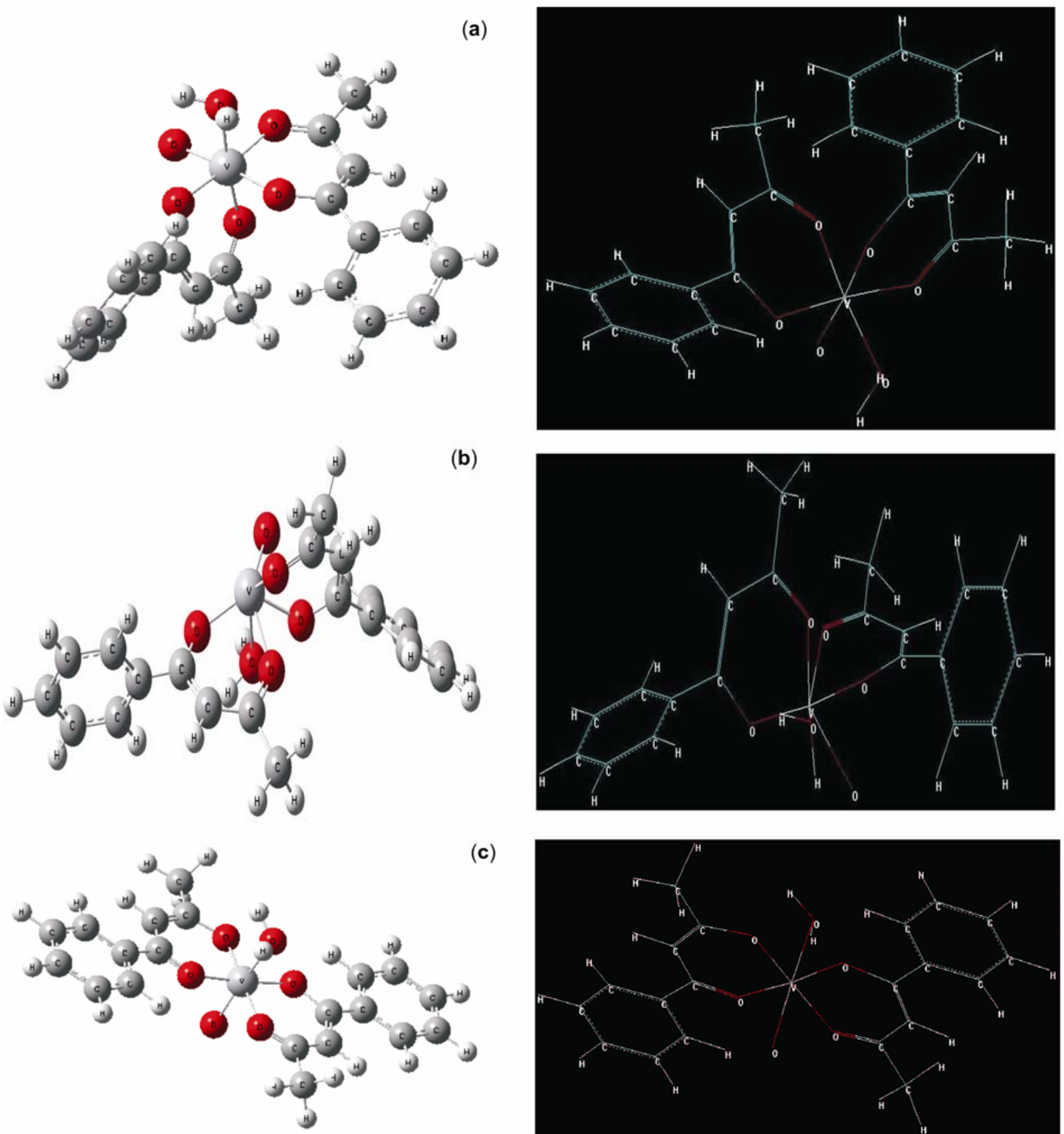

(c)

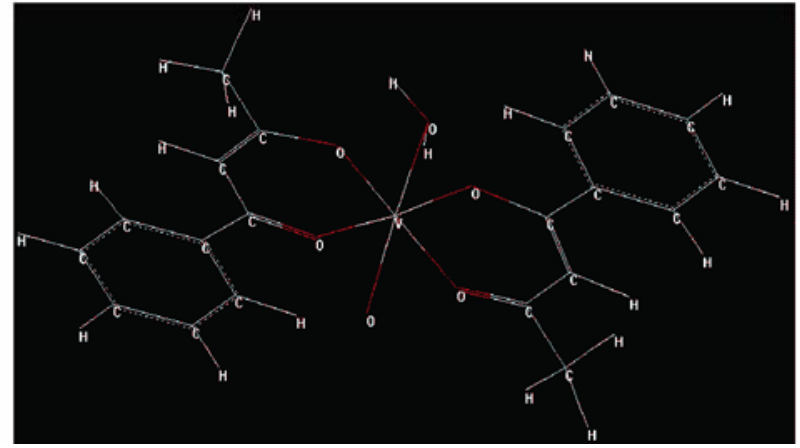

Appendix 1. The structure of the (a) cis- $\left[\mathrm{VO}(\mathrm{phac})_{2}\left(\mathrm{H}_{2} \mathrm{O}\right)\right]$ complex, (b) trans- $\left[\mathrm{VO}(\mathrm{phac})_{2}\left(\mathrm{H}_{2} \mathrm{O}\right)\right]$ complex and (c) trans $-\left[\mathrm{VO}(\text { phac })_{2}\left(\mathrm{H}_{2} \mathrm{O}\right)\right]\left(\mathrm{O}\right.$ and $\left.\mathrm{H}_{2} \mathrm{O}\right)$ complex.

absorption was the maximum after equilibrium. The formed complex shows different absorption from the free ligand, while the metal ion solution shows no absorption at those wavelengths. As an example, the variation of the electronic spectra for dfac, titrated with various concentrations of $\mathrm{VO}\left(\mathrm{SO}_{4}\right) \cdot n \mathrm{H}_{2} \mathrm{O}$ at $25^{\circ} \mathrm{C}$ in $\mathrm{MeOH}$ is shown in figure 4 . The same procedure was followed for all other systems. The electronic spectra of the formed complexes were the same as the electronic spectra of the separately synthesized complexes.
The formation constants, $K_{f}$, were calculated using SQUAD computer program, ${ }^{36}$ designed to calculate the best values for the formation constants of the proposed equation model (1) by employing a non-linear, least-squares approach. Also, the free energy change $\Delta G^{\circ}$ values of the formed complexes were calculated from $\Delta G^{\circ}=-\mathrm{RT} \ln K_{f}$ at $25^{\circ} \mathrm{C}$ (see table 4 ).

$$
\begin{aligned}
& 2 \mathrm{HL}+\mathrm{VO}\left(\mathrm{SO}_{4}\right) \cdot n \mathrm{H}_{2} \mathrm{O} \longrightarrow \\
& {\left[\mathrm{VO}(\mathrm{L})_{2}\right] \cdot n \mathrm{H}_{2} \mathrm{O}+\mathrm{SO}_{4}^{2-}+2 \mathrm{H}^{+} . }
\end{aligned}
$$


The results in table 4 show that for $\operatorname{VO}(0)_{4}$-type complexes, the steric character of the ligands predominates the electronic factor toward VO(IV) center. Concerning this effect, tfac has more tendency to bind with VO(IV) center than phac and dphac.

As far as $\mathrm{VO}(\mathrm{N})_{4}$-type complexes are concerned, the electron withdrawing functional groups such as bromo, chloro and cyano make the Schiff base as a poor donor ligand toward VO(IV) center. On the other hand, the electron donating groups such as hydroxy or methoxy make the ligand more potent donor toward the VO(IV) center, although the steric effect of the substitution cannot be ruled out. Therefore, $p$-Hydroxypyran, $p$-MeOpyran and pyran have the highest tendency toward VO(IV).

\section{Conclusion}

The structural, geometrical, thermal, and thermodynamic properties of the oxovanadium(IV) complexes have been investigated. According to the thermodynamic studies, the formation constants of the complexes depend upon the steric and the electronic characteristic of the ligands. But as the steric character predominating, the tendency to bind with VO(IV) center decrease. Moreover, the electrical feature of each complex has an important role on the thermodynamic and the thermal properties. It is evident that there is a close relationship between these various properties. Charge distribution and the geometry are effective factors affecting the properties of the different complexes. The way that thermal properties change is the same as the variation of the QSAR properties for $\mathrm{VO}\left(\mathrm{O}_{4}\right)$-type complexes.

\section{Acknowledgements}

We thank Shiraz University Research Council for financial support.

\section{Supplementary information}

For supplementary information see www.ias.ac.in/ chemsci website.

\section{References}

1. Mohammadi K, Thompson K H, Patrick B O, Storr T, Martins C, Polishchuk E, Yuen V G, McNeill J H and Orvig C 2005 J. Inorg. Biochem. 992217

2. Crans D C 2000 J. Inorg. Biochem. 80123

3. Maurya R C and Rajput S 2004 J. Molecular Struct. 68734
4. Plass W 2003 Coord. Chem. Rev. 237205

5. Rehder D 2003 Inorg. Chem. Commun. 6604

6. Aranha P E, Souza. M, Romera S, Ramos L A, Santos M, Dockal E and Cavalheiro E T G 2007 Thermochim. Acta 4539

7. Ahmad S, Isab A A, Ali S and Al-Arfaj A R 2006 Polyhedron 251633

8. Posner B I, Shaver A and Fantus I G 1990 in New antidiabetic drugs (eds) C J Bailey and P R Flatt (Gordon London S), p. 107

9. Posner B I, Faure R, Burgess J W, Bevan A P, Lachance D, Zhang-Sun G, Fantus I G, Hall D A, Lum B S and Shaver A 1994 J. Biol. Chem. 2694596

10. Shaver A, Hall D A, Ng J B, Lebuis A M, Hynes R C and Posner B I 1995 Inorg. Chim. Acta 229253

11. Shaver A, Ng J B, Hall D A, Soo Lum B and Posner B I 1993 Inorg. Chem. 323109

12. Kadota S, Fantus I G, Deragon G, Guyda H J, Hersh B and Posner B I 1987 Biochem. Biophys. Res. Commun. 147259

13. McNeill J H, Yuen V G, Hoveyda H R and Orvig C $1992 \mathrm{~J}$. Med. Chem. 351489

14. Caravan P, Gelmini L, Glover N, Herring F G, Li H, McNeill J H, Rettig S J, Setyawati I A, Shuter E, Sun Y, Tracey A S, Yuen V G and Orvig C $1995 \mathrm{~J}$. Am. Chem. Soc. 11712759

15. Li J, Elberg G, Crans D C and Shechter Y 1996 Biochem. 358314

16. Morgan G T and Moss H W 1914 J. Chem. Soc. 10378

17. Kaneda K, Jitsukawa K, Itoh T and Teranishi S 1980 J. Org. Chem. 453004

18. Hirao T 1997 Chem. Rev. 972707

19. Wender P A, Rice K D and Schnute M E $1997 \mathrm{~J}$. Am. Chem. Soc. 1197897

20. Taguchi $H$, Isobe $K$, Nakamura $Y$ and Kawaguchi $S$ 1975 Chem. Lett. 757

21. Selbin J, Manning H R and Cessac G 1963 J. Inorg. Nucl. Chem. 21253

22. Atherton N M, Gibbon P J and Shohoji M C B 1982 J. Chem. Soc. Dalton Trans 2289

23. Dodge R P, Templeton D H and Zalkin A 1961 J. Chem. Phys. 3555

24. Amin S, Cryer K, Zhang B, Dutta S, Eaton S, Anderson O, Miller S and Crans D 2000 Inorg. Chem. 39 406

25. Frisch M J, Trucks G W, Schlegel H B, Scuseria G E, Robb M A, Cheeseman J R, Montgomery J A, Kudin K N, Burant J C, Millam J M, Iyengar S S, Tomasi J, Barone V, Mennucci B, Cossi M, Scalmani G, Rega N, Petersson G A, Nakatsuji H, Hada M, Ehara M, Toyota K, Fukuda R, Hasegawa J, Ishida M, Nakajima T, Honda Y, Kitao O, Nakai H, Klene M, Li X, Knox J E, Hratchian H P, Cross J B, Adamo C, Jaramillo J, Gomperts R, Stratmann R E, Yazyev O, Austin A J, Cammi R, Pomelli C, Ochterski J W, Ayala P Y, Morokuma K, Voth G A, Salvador P, Dannenberg J J, Zakrzewski V G, Dapprich S, Daniels A D, Strain M C, Farkas O, Malick D K, Rabuck A D, Raghavachari K, Foresman J B, Ortiz J V, Cui Q, Baboul A G, Clifford S, Cioslowski J, Stefanov B B, Liu G, Liashenko A, Piskorz P, 

Komaromi I, Martin R L, Fox D J, Keith T, Al-
Laham M A, Peng C Y, Nanayakkara A, Challacombe M, Gill P M W, Johnson B, Chen W, Wong M W, Gonzalez C and Pople J A 2003 (Pittsburgh PA: Gaussian, Inc)

26. Ghose A K, Pritchett A and Crippen G M 1994 J. Comput. Chem. 980

27. Rogers D and Hopfinger A J $1994 \mathrm{~J}$. Chem. Inf. Comput. Sci. 34854

28. Bodor N, Gabanyi Z and Wong C $1989 \mathrm{~J}$. Am. Chem. Soc. 1113783

29. Ooi T, Oobatake M, Nemethy G and Scheraga H A 1987 Proc. Natl. Acad. Sci. USA 843086
30. Viswanadhan V N, Ghose A K, Revankar G N and Robins R K 1989 J. Chem. Inf. Comput. Sci. 29163

31. Ghose A K and Crippen GM 1987 J. Chem. Inf. Comput. Sci. 2721

32. Selwood P W 1956 Magnetochemistry (New York: Interscience)

33. Symal A 1975 Coord. Chem. Rev. 21309

34. Selbin J 1966 Coord. Chem. Rev. 1293

35. Abdel-Ghani N T and Sherif O E 1989 Thermochim. Acta 15669

36. Leggett D L 1985 Computational methods for the determination of formation constant (New York: Plenum Press) 